\title{
PENDIDIKAN MORAL: ANTARA HARAPAN DAN REALITAS
}

\author{
Oleh: Abdul Rahman Barakatu*
}

\begin{abstract}
The application of moral education has honest aim. The Educational Institution is expected able to educate every learner in order to have behavior based on valid moral code. They are honest, believable, altruistic, sensible, and able to make relationship without breaking norm and another good action. This hope can be enlarged. The out put of educational Institution is expected to have morality consistently in daily relationship among the society. Even though the reality shows that its aims and hope have been reached yet. The phenomenon seems that the behavioral diverge from moral value such as; cheating, dishonest, mass fighting, violence, exportation and so on. This moral diverge, of course has causality. The causality can be divided into four aspects, namely; cultural system, educational system, internal learner's condition, and external influencing the learner's psychological development.
\end{abstract}

KEYWORDS: Pendidikan moral, disonansi kognitif, krisis keteladanan, permisivisme, hedonis.

KETIKA tawuran massal terjadi lagi antara mahasiswa Universitas Kristen Indonesia dan mahasiswa Yayasan Administrasi Indonesia Universitas Persada Jakarta, kalangan masyarakat merasa pessimis terhadap upaya pembinaan nilai-nilai moral. ${ }^{1}$ Pessimisme menggeluti pikiran masyarakat karena banyak pihak yang diharapkan berperilaku moral, malah menyimpang dari ukuran standar nilai moral yang berlaku. Hampir setiap hari masyarakat menyaksikan penyimpangan standar moral, seperti berbagai tindak kekerasan, pemerasan, pelecehan seksual, fedopolia, penipuan, kecurangan dalam ujian, penggunaan ijazah palsu, pembunuhan sadis dengan cara mutilasi, perkelahian massal, praktek suap, korupsi dan lainlain. Meereka menyaksikan atau membaca peristiwa tersebut melalui media cetak dan media elektronik. Pelakunya pun berasal dari berbagai

\footnotetext{
*Magister Pendidikan dalam bidang Bimbingan dan Konseling dari Program Pascasarjana Universitas Negeri Malang ini adalah dosen pengampu mata kuliah Psikologi Perkembangan pada Fakultas Tarbiyah dan Keguruan UIN Alauddin Makassar.
} 
kalangan mulai dari siswa, mahasiswa, birokrat, politisi bahkan penegak hukum. Perilaku moral terjun bebas menurun mendekati titik nadir.

Pada waktu siswa SMAN 70 Jakarta, salah satu sekolah unggulan, melakukan pemerasan, kekerasan, dan pelecehan seksual terhadap yuniornya, maka yang menjadi sorotan kegagalan pembinaan moral adalah dunia pendidikan. ${ }^{2}$ Apalagi sebelumnya beberapa mahasiswa, sebuah perguruan tinggi yang mendidik pamong praja, diberitakan meninggal akibat mengalami tindak kekerasan yang dilakukan kakak tingkatnya. Belum lagi perilaku siswi SMA yang menjadi anggota geng Nero di Jepara yang menyiksa anggotanya. Singkatnya, dunia pendidikan pun menjadi buram karena dianggap tidak berhasil menanamkan nilai-nilai moral. Harapan masyarakat terhadap dunia pendidikan menjadi luntur. Akibatnya, Pelaksanaan pendidikan moral di sekolah atau lembaga pendidikan formal menuai kritik yang sangat pedas dan memunculkan berbagai ulasan.

Pembahasan mengenai pendidikan moral mempunyai cakupan yang cukup luas dengan aneka ragam pandangan. Pendidikan moral pun dapat ditinjau dari berbagai aspek seperti landasan psikologis pembinaan moral, perbedaan pandangan moral antara anak laki-laki dan anak perempuan, aplikasi prinsip psikologis dalam upaya pendidikan moral dan lain-lain. Bahkan perdebatan panjang terjadi apakah pendidikan moral harus dilaksanakan di lembaga pendidikan formal atau dikembalikan saja menjadi kewenangan rumah tangga. ${ }^{3}$

Ruang lingkup pembahasan pendidikan moral yang sangat luas, menyebabkan penulis akan membatasi diri dengan hanya mengulas dua permasalahan pokok. Pertama, harapan yang ditumpukan kalangan masyarakat kepada lembaga pendidikan sebagai pelaksana pendidikan moral. Kedua, faktor-faktor psikologis yang mempengaruhi kemerosotan perilaku moral siswa. Kedua hal ini akan diuraikan satu persatu untuk mengembalikan peran sekolah sebagai pemegang amanah yang diharapkan mampu melaksanakan nation and character building.

\section{PERAN LEMBAGA PENDIDIKAN DALAM PEMBINAAN MORAL}

Para psikolog mengemukakan bahwa "morals are generally defined... as attitude and beliefs that people hold that help them decide that is right and wrong"4 Martin, B. L. \& Briggs, L. J. memperluas jangkauan pengertian moral sebagai "the principle of right and wrong, a conception of right behavior, making a right decision, or conforming to the standards of right behavior".5 Dengan demikian, moral sangat berkaitan dengan sikap dan keyakinan yang dianut oleh seseorang yang membantunya mempertimbangkan dan mengambil keputusan untuk melakukan perbuatan baik atau salah berdasarkan prinsip-prinsip dan konsep moral. 
Tindakan moral tidak berdiri sendiri secara terpisah dalam kepribadian individu. Tindakan moral merupakann akumulasi dari berbagai komponen kepribadian. Elliot, S. N., Kratochwill, T. R., Cook, J. L., \& Travers, J. E. mengemukakan bahwa "moral behavior is a complex mixture of cognition (thinking about what todo), emotion (feling about what do or what was done), and behavior (what is actually done)."6 Purwakania Hasan menjelaskan bahwa komponen afektif moralitas terdiri dari berbagai jenis perasaan seperti perasaan bersalah, atau malu, perhatian terhadap perasaan orang lain, dan sebagainya. Komponen kognitf adalah konseptualisasi benar dan salah dan pengambilan keputusan tentang bagaimana seseorag berperilaku. Komponen perilaku mencerminkan bagaimana seseorang sesungguhnya berperilaku ketika menghadapi suatu kondisi. ${ }^{7}$

Dalam masyarakat apapun terdapat suatu norma yang dianut bersama sebagai pedoman perilaku. Pedoman perilaku tersebut tumbuh berkembang bersama dengan eksistensi suatu masyarakat. Salah satu pedoman perilaku tersebut adalah kode moral. Pedoman perilaku itu berasal dari nilai-nilai luhur yang dijunjung tinggi dalam dan diwariskan oleh suatu masyarakat. Clabaugh mengemukakan bahwa "Judgement of right and wrong are based on remnant of past culture." 8 Norma perilaku tersebut berperan menata tata kehidupan bersama para anggotanya. Kehilangan norma perilaku yang berakarkan budaya akan menjadikan masyarakat tersebut akan kehilangan identitas dan sangat mudah tercederai dengan apa yang disebut dengan cultural shock.

Martin Huffman menyatakan bahwa sebenarnya akar moralitas terdapat dalam empati. ${ }^{9}$ George, R. L., \& Cristiany T. S. mengemukakan bahwa "Empathy is the ability to respon sensitively and acurately to the one's feelings and expeerience as if they were his own. Empathy is the ability to adopt the individual's Internal frame of reference." 10 Empati mampu mengembangkan kepribadian individu untuk memelihara dirinya tetap berada dalam koridor simbiosis mutualism. Individu akan terkontrol kepribadiannya untuk berbuat baik, karena individu yang memiliki rasa empati yang dalam mampu merasakan bahwa perbuatan yang tidak bermoral akan menyakiti orang lain dan merugikan kemanusiaan. Hal ini disebabkan karena empati mempunyai dua komponen dasar yakni sensitif dan perseptif. Sensitif adalah keterampilan afektif yang tumbuh dari kesadaran dan kepedulian individu sehingga mampu mengidentifikasi perasaan orang lain. Perseptif adalah keterampilan kognitif untuk memahami dan mengidentifikasi stimulus yang memicu perasaan orang lain. ${ }^{11}$

Sekolah berfungsi mengembangkan rasa empati sebagai akar moral. Sekolah bukan hanya berperan sebagai transfer of knowledge. Schloss P. J. \& 
Smith M. A. menyatakan "a primary goal of education is to influence the development of positive social, emotional, academic and vocational skills, which enhance our students' ability to control their own lives."12 Sekolah berperan mengembangkan kemampuan empatik siswa untuk mengontrol kehidupan mereka sendiri menjadi orang yang memiliki pertimbangan dan perasaan moral yang tepat. Erzioni mengemukakan bahwa sekolah memiliki posisi sentral dalam membina karakter dengan menanamkan disiplin diri dan empati, yang pada gilirannya memungkinkan keterlibatan tulus terhadap nilai peradaban dan moral. ${ }^{13}$

Sekolah merupakan komunitas moral yang anggotanya terikat dengan konsensus yang mendalam dan meluas untuk mempraktekkan cara-cara dan tujuan-tujuan hidup. ${ }^{14}$ Oleh karena itu sekolah menjadi tulang punggung utama dari suatu sistem kemasyarakatan yang menjunjung tinggi nilai-nilai moral. Memiliki komitmen dan kepedulian yang mendalam terhadap pembinaan moral. Menurut John Dewey pendidikan moral paling ampuh bila diajarkan kepada anak dalam pagelaran peristiwa nyata, bukan sebagai pelajaran abstrak. ${ }^{15}$ Pendidikan moral tidak cukup dengan menceramahi anak dengan nilai-nilai, karena hal tersebut menjadikan pengajaran hambar tidak bermakna.

Sekolah mempunyai tanggung jawab mengembangkan moral siswa sebagai bagian pengembangan kepribadian secara menyeluruh. Shaver mengungkapkan bahwa "... the school are assumed tobe responsible for improving students. Thinking and decision making abilities, and that this is as true in the realm of values as it is in mathematics and science. He describes three types of values important to schooling about which students should be engaged: esthetic values, instrumental values and moral values. ${ }^{16}$ Bahkan Dryden, G \& Vos, J 103-104 secara tegas mengemukakan bahwa sekolah mempunyai "...the responsibility for the moral training. ${ }^{17}$ Dengan demukian, sekolah akan memainkan peran; Learning as forming character; Learning as gaining understanding, and; Learning as skills acquisition. ${ }^{18}$

Sebenarnya setiap ilmu yang diajarkan di sekolah mengandung nilai moral. Pelajaran sejarah dapat diberi muatan moral betapa kemanusiaan hancur karena peperangan. Pelajaran ekonomi dapat mengungkapkan pengaruh resesi terhadap pertambahan pengangguran. Samuel Smile menyatakan bahwa "it is not then how much a man may know, but the end and purpose for which he knows it. The object of knowledge should be to mature wisdom and improve character, to render us better, happier and more usefull, more benevcient, more energetic, and more efficient in the pursuit of every high purpose in life. 19

Dalam upaya penataan pendidikan yang berorientasi kepada pembentukan karakter, Unesco merumuskan the four pillars of education yakni; 
Learn how to know; Learn how to to do; Learn how to be; Learn how to live together. ${ }^{20}$ Pilar pendidikan tersebut merupakan konsep pendidikan yang memandang manusia sebagai satu kepribadian yang utuh. Manusia bukan hanya membutuhkan pengetahuan. Mereka juga membutuhkan karakter dengan pegangan moral yang kuat dalam membina kehidupan bersama dalam tatanan simbiosis mutualistis. William Damon, seorang pakar perkembangan moral di Brown University Amerika, mengemukakan bahwa untuk menjadi manusia bermoral anak-anak harus mendapatkan keterampilan emosional dan sosial sebagai berikut:

* Mereka harus mengikuti dan memahami perbedaan antara perilaku yang "baik" dan yang "buruk" dan mengembangkan kebiasaan dalam hal perbuatan yang konsisten dengan sesuatu yang dianggap baik.

* Mereka harus mengembangkan kepedulian, perhatian, dan tanggung jawab atas kesejahteraan dan hak-hak orang lain yang diungkapkan melalui sikap peduli, dermawan, ramah dan pemaaf.

* Mereka harus merasakan reaksi emosi negatif seperti malu, bersalah, marah, takut, dan rendah bila melanggar aturan moral. ${ }^{21}$

Masyarakat menumpukan harapan kepada sekolah sebagai lembaga pendidikan yang dapat memainkan peran strategis mewariskan normanorma moral. Sekolah diharapkan mampu mengembangkan wawasan pertimbangan moral dan perasaan moral siswa sehingga mereka mampu mengambil keputusan moral untuk berperilaku moral sesuai dengan nilainilai kebajikan.

\section{PENYEBAB KEMEROSOTAN MORAL}

Keprihatinan terhadap kemerosotan moral sudah menjadi perhatian banyak kalangan sejak lama. Shapiro mengutarakan bahwa di Amerika sendiri sudah empat dasawarsa terakhir setiap orang-dari kepala sekolah dasar sampai kepada penghotbah dan presiden-telah berusaha sekuat tenaga mengatasi krisis perkembangan moral, tetapi makin lama keadaan justru semakin memburuk. ${ }^{22}$

Pertanyaan yang muncul ke permukaan kesadaran kita adalah "mengapa terjadi kemorosotan moral khususnya di kalangan para kaum terpelajar. Muhtar Lubis menganalisisnya dari sudut budaya. Dia melukiskan manusia Indonesia sebagai hipokrit alias munafik, enggan bertanggung jawab atas keputusannya, berjiwa feodal, percaya takhayul, artistik, dan berwatak lemah. ${ }^{23}$ Hanya satu sifat yang positip yakni artistik, sifatsifat lainnya negatif. Sifat-sifat kepribadian yang negatif ditengarai sebagai biang kerok penyebab timbulnya berbagai perilaku tidak terpuji seperti 
korupsi, disiplin kerja yang lemah, kemauan belajar yang rendah, suka menyontek, terlibat dalam tawuran, dan sebagainya.

Kemerosotan moral juga diperparah dengan sistem pembelajaran verbal yang sifatnya mencekoki siswa. Martin, B. L \& Briggs, L. J mengemukakan bahwa "The educational system has been severely criticized by many because of its lack of attention to the overall development of student. This include not only lack of provision for a climate of self-development, but a concomitant lack of concern about the development of the learner's attitude, values and feeling. ${ }^{24}$

Di samping kedua pandangan tersebut di atas, kemerosotan moral juga disebabkan oleh beberapa faktor. Faktor-faktor tersebut adalah; disonansi kognitif, krisis keteladan, kebingungan identitas, relativisme moral, permisivisme, dan gaya hidup hedonis.

\section{Disonansi Kognitif}

Pertentangan realitas dengan kode moral itu mempengaruhi konsistensi kognitif seseorang. Festinger menjelaskan hal ini dengan mengemukakan teori disonansi kognitif yakni "an explanation of the discomfort people feel when new perception or behavior clash with long-held beliefs. ${ }^{25}$ Dia mengasumsikan adanya suatu situasi yang menekan konsistensi sikap dan perilaku individu dengan cara yang tidak terpuji. ${ }^{26}$ Pelaksanaan ujian yang dipenuhi dengan kecurangan akan mendistorsi ajaran moral, seperti kejujuran, yang diperoleh siswa di dalam ruangan kelas. Keadaan yang bersifat antagonistis memberikan tekanan terhadap daya kognitif individu. Siswa yang terbiasa bertahan dengan prinsip moral tetapi kesulitan menjawab soal akan mengalami disonansi kognitif melihat temantemannya menyontek atau mendapatkan bantuan yang tidak dibenarkan menurut aturan ujian. Siswa-siswa tersebut menjadi goyah dan kemudian menyontek melanggar norma moral.

Kasus kebocoran soal ujian sekolah menengah, kasus pemerasan, kasus suap yang biasa terjadi karena adanya sumber penekan daya kognitif. Penekan daya kognitif menyebabkan kepala sekolah atau guru berusaha mencari soal ujian atau membocorkan ujian sebelum waktu pelaksanaan. Demikian juga pergaulan bebas mempengaruhi sikap dan perilaku orang untuk mengikutinya. Pendeknya, disonansi kognitif menggoyahkan sendir-sendi moral seseorang.

\section{Krisis Keteladanan}

Siswa membutuhkan tokoh idola yang dapat dijadikan teladan. Bandura mengemukakan konsep model dalam teori belajar sosial. Model 
akan ditiru oleh anak melalui cara belajar observasi atau melalui vicarious learning. ${ }^{27}$ Namun, sangat kurang tokoh idola yang mampu memberikan contoh perilaku moral.

Remaja yang berada dalam masa sturm und drung kurang mendapatkan tokoh idola yang dapat dijadikan panutan moral. Tayangan terbuka di televisi menjadikan mereka lebih banyak menjadikan artis atau selebritis menjadi idola. Mereka, kemudian, meniru cara berperilaku, berbahasa, berpakaian, bergaul yang biasanya sudah berada di luar koridor aturan moral. Tokoh yang dianggap terhormat dapat menampilkan perilaku moral, menjadi rontok citranya karena perilaku mereka yang tidak dapat diteladani. Anggota dewan yang berkelahi atau tidur di ruang sidang, menerima suap dari berbagai rekanan. Bahkan ada anggota dewan yang terlibat dalam adegan syur dengan sekretarisnya. Sebelumnya sudah tersebar rekaman adegan yang hampir serupa dari seorang anggota dewan lainnya yang sedang asyik bercumbu dengan seorang artis penyanyi dang dut yang bukan isterinya. Perilaku ini dipandang tidak benar dari sisi kode perilaku moral dan tidak selayaknya dilakukan orang-orang terhormat. Hal serupa sudah dilakukan oleh sebagian remaja kita dan tanpa merasa risih merekam perbuatan mereka melalui telpon genggam.

\section{Kebingungan Identitas}

Pada masa remaja, para siswa akan mengalami krisis identitas berkaitan dengan peran yang akan dimainkannya. Mereka mencari jawaban dari pertanyaan Who am I? ${ }^{28}$ Krisis identitas terjadi karena "adolescent are caught between two major systems, both of which are in flux. They have to cope with internal, cognitive and glandular changes at he same time that they are confronting a series of inconsistent and changing external regulations. ${ }^{29}$ Krisis identitas menyebabkan remaja mengalami ketegangan,30 Mereka kebingungan menghadapi realitas disertai dengan perasaan gelisah dan cemas. Mereka terkadang mengatasi keadaan ini dengan reaksi tindakan kekerasan seperti berontak dan melawan segala bentuk otoritas termasuk guru dan orang tua. Mereka pun melanggar norma-norma moral yang ada. Mereka berlaku bengis seperti yang dilakukan oleh geng Nero atau geng motor yang sering diberitakan melalui televisi. Mereka bingung terhadap nilai-nilai yang sudah mapan berkembang dalam masyarakat. ${ }^{31}$

Kekerasan yang mereka tujukan keluar, kepada sesamanya dan orang lain, kelihatannya adalah refleksi kegalauan yang terjadi di dalam diri mereka. ${ }^{32}$ Mereka terombang-ambing untuk menentukan suatu pilihan mempersiapkan identitas pribadi. Kebingungan identitas membawa remaja kepada perilaku menyimpang. Mereka mencari penyaluran dengan 
perbuatan-perbuatan yang kurang bermoral. Narkotika merupakan salah satu penyaluran kebingungan identitas. Oleh karena itu Conger J. J. mengemukakan bahwa "... the problem of developing a strong sense of identity cannot be separated from the problem of values. If young people are to maintain some stability in their conception of self and in their internal guides to action they must be faithful to some basic values." 33 Remaja yang mengalami kebingungan identitas tidak hanya gagal melakukan peralihan tetapi juga membentuk kode moral berdasarkan konsep moral yang secara sosial tidak dapat diterima. ${ }^{34}$ Hal ini terjadi karena mereka tidak mampu mengembangkan daya kognitif seperti yang digambarkan oleh Piaget yakni "...is characterized by development of the capacity to think abstractly and to generate alternative hyphoteses and test them against evidence. ${ }^{35}$

\section{Relativisme Moral}

Relativisme moral beranggapan bahwa nilai moral bersifat relatif. Individu dapat saja menganggap benar apa saja yang diperbuatnya. Moral itu bergantung pada persepsi pandangan setiap individu. Tiap orang memiliki "kumpulan kebajikannya sendiri." 36 Conger J. J. mendeskripsikan bahwa "They belief that there are no absolute standard of right and wrong and that one set of beliefs or values may be no better or worse than another set. ${ }^{37}$ Anak gadis yang memakai baju dengan memperlihatkan pusatnya tidak dianggap sebagai sesuatu yang tabu dan bukan menjadi ukuran moral. Siswa beranggapan bahwa bukan lagi waktunya ujian tidak melihat buku yang terpenting adalah lulus dengan menempuh jalan apa saja.

Pandangan ini sangat berpengaruh terhadap perilaku moral anak yang bisa saja mengganggu sendi-sendi kehidupan masyarakat. Seorang remaja dapat saja menjalankan motornya dengan gas penuh di tengah malam dengan suara motor yang meraung-raung. Mereka tidak akan merasa bahwa orang lain terganggu dengan ulahnya yang tidak sesuai dengan norma kebajian yang ada.

\section{Permisivisme}

Remaja memiliki gaya hidup yang berbeda dengan orang dewasa. Salah satu gaya hidup yang biasa menyelimuti kehidupan remaja adalah permisivisme. Permisivisme sudah cenderung menjadi gaya hidup yang membolehkan semua dapat dilakukan tanpa ikatan norma apapun termasuk norma moral. Gaya pacaran di kalangan remaja. Mode pakaian di tengah kerumunan orang. Praktek politik yang menghalalkan segala cara. Hidup samen lepen tanpa ikatan pernikahan. Acuh terhadap aturan moral dalam pergaulan. Semuanya merupakan refleksi gaya hidup permisivisme. 
Permisivisme menganggap bahwa moral adalah sesuatu yang mengikat dan mengurangi kebebasan manusia. Padahal, manusia adalah mahluk yang memiliki kebebasan dan mempunyai hak untuk memilih serta menentukan sendiri gaya hidup yang diinginkannya.

Permisivisme adalah suatu racun yang mematikan kode moral dalam kehidupan bermasyarakat. Masyarakat terbiasa hidup tanpa ikatan kode moral yang dianggap sebagai pola hidup yang sudah tertinggal dan tidak dibutuhkan lagi. Kode moral adalah yang sesuai dengan perkem-bangan dan keinginan mutlak setiap individu.

\section{Gaya hidup Hedonis}

Keinginan untuk memperoleh kenikmatan hidup berlebih dapat mendorong individu untuk berperilaku melanggar kode moral. Pelayanan rumah sakit yang sering mengabaikan keselamatan pasien, pengurusan KTP yang terlambat, praktek korupsi yang merajalela sangat berkaitan dengan pola kehidupan hedonis materialistik. Pola hidup yang menghalalkan segala cara untuk mendapatkan materi demi untuk kenikmatan. Semuanya diukur dengan materi. Moral adalah materi yang dapat memberikan kenikmatan. Perilaku ini terekam dalam memori siswa sehingga mereka juga melakukan berbagai macam perbuatan yang melanggar kode moral. Pemerasan kepada siswa yunior yang diikuti dengan tindak kekerasan merupakan contoh manifestasi keinginan menikmati gaya hidup hedonis. Freud mengulas bahwa prinsip kenikmatan berasal dari dorongan unsur kepribadian yang bernama Id. Id memiliki sumber energi yang mempengaruhi kehidupan manusia. ${ }^{38}$ Prinsip hidup ini sudah merambah dalam kehidupan remaja dengan mengabaikan prinsip-prinsip moral.

\section{KESIMPULAN}

Interaksi sosial manusia yang harmonis selalu dilandasi kode moral. Kode moral mengandung prinsip-prinsip tentang yang baik dan buruk yang dijadikan seorang individu untuk mempertimbangkan, memilih, memutuskan dan bertindak. Kode moral diwariskan melalui upaya pendidikan dengan tujuan agar individu dapat menata kehidupannya secara selaras sesama manusia bahkan dengan lingkungan hidupnya. Sekolah sebagai lembaga pendidikan formal diharapkan mampu memainkan peran membina moral sehingga siswa menjadi orang yang bijak, memiliki karakter yang baik, menghayati dan berperilaku sesuai nilai-nilai moral berdasarkan pertimbangan matang dan pemikiran yang jernih. Dengan demikian berbagai perilaku dan pelanggaran moral yang terjadi dapat di hindari. Pemerasan, pelecehan seksual, kekerasan, keculasan, penipuan dan sebagainya tidak lagi menjadi warna kehidupan yang menghiasi 
kehidupan remaja dan masyarakat.

Pendidikan moral menghadapi berbagai hambatan dan rintangan. Hambatan dan rintangan tersebut mempengaruhi keadaan psikologis siswa sehingga mereka tergiring untuk bertindak di luar kode moral yang berlaku. Hambatan dan rintangan tersebut beragam, mulai dari hambatan budaya, sistem pendidikan, dan suasana psikogis siswa serta faktor eksternal lainnya. Hambatan budaya terdiri atas sejumlah sifat-sifat negatif yang melekat dan membudaya dalam kehidupan seperti munafik, enggan bertanggungjawab, berjiwa feodal, percaya takhayul, dan berwatak lemah.

Hambatan berikutnya adalah sistem pendidikan yang berlaku. Pendidikan dianggap terlalu bersifat verbalistis intelektualistis dengan mengabaikan pembinaan kepribadian. Pendidikan dianggap masih kurang mengembangkan empati sebagai akar moralitas yang mendasari perasaan dan pertimbangan moral. Dengan demikian siswa kurang memiliki kesempatan untuk menginternalisasi nilai-nilai moral yang akan mampu meningkatkan keterampilan untuk mengontrol perilakunya sendiri

Faktor internal dan faktor eksternal juga menyebabkan berbagai hambatan psikologis terhadap penghayatan nilai moral. Hambatanhambatan yang bersifat internal adalah disonansi kognitif, kebingungan identitas, permisivisme, dan gaya hidup hedonis. Sedangkan faktor eksternal terdiri dari krisis keteladan dan paham permisivisme.

\section{CATATAN AKHIR:}

1. Bulletin siang, RCTI, tanggal 2008

2. Bulletin siang

3. Gary K. Clabaugh, \& Edward G. Razycki, Understanding School: The Fundamental of Education, New York: Harper \& Row. 1990. h. 536.

4. Lawrence Kohlberg (1963, The development of Children's Orientations toward a moral order; Sequence in the developmen of moral thought, (in Roger R. Hock (1999), Forty Studies that Changed Psychology, Upper Saddle River, New Jersey: Prentice Hall, h. 199.

5. Barbara L. Martin \& Leslie J. Briggs, The Affective and Cognitive Domain: Integration for Instruction and Research, Englewood Cliffs, New Yersey: Educational Technology Publication, Inc. 1986, h. 145

6. Stephen N. Elliot, S. N., Thomas R. Kratochwill, Joan Littlefield Cook \& John E. Travers, Educational Psychology: Effective Teaching, Effective Learning ( ${ }^{\text {rd }}$ ed.), Boston: McGraw Hill, h. 83.

7. Aliah B. Purwakania Hasan, Psikologi Perkembangan Islami: Menyingkap Rentang Kehidupan Manusia dari Prakelahiran Hingga Pasca Kematian, Jakarta: Raja Grafindo Persada, 2006, h. 262.

8. Gary K. Clabaugh \& Edward G. Razycki, Understanding School: The Fundamental of Education, h. 618. 
9. Daniel Goleman, Emotional Intelligenc, (Terjemahan Hermaya dengan judul "Emotional Intelligence; Kecerdasan Emosional) Jakarta: Gramedia Pustaka Utama, 1997, h. 149.

10. Rickey L. George \& Therese S. Cristiani, Counseling: Theory and Practice ( $3^{\text {rd }}$ ed.), Needham Heights, MA: 1990, h. 130.

11. Rickey L. George \& Therese S. Cristiani, Counseling: Theory and Practice ( $3^{\text {rd }}$ ed.), h. 130.

12. Patrick. J. Schloss \& Maureen A. Smith, Applied Behavior Analysis in the Classroom, Needham Heights, MA: Allyn and Bacon, 1994, h. 26.

13. Daniel Goleman, Emotional Intelligence, h. 406.

14. Gary K. Clabaugh \& Edward G. Razycki, Understanding School: The Fundamental of Education, h. 28.

15. Daniel Goleman, Emotional Intelligence, h. 407

16. Barbara L. Martin \& Leslie J. Briggs. The Affective and Cognitive Domain: Integration for Instruction and Research, h. 147.

17. Gordon Dryden \& Joannette Vos, The Learning Revolution: The Change the Way the World Learns, Torrance, CA, USA: The Learning Web, 1999, h. 103.

18. Gary K. Clabaugh \& Edward G. Razycki, Understanding School: The Fundamental of Education, h. 618.

19. Gary K. Clabaugh \& Edward G. Razycki, Understanding School: The Fundamental of Education, h. 618.

20. Marsetio Donosepoetro, "Dinamika Perubahan Masyarakat dan Proses Pendidikan Nasional", Makalah, disampaikan pada Seminar Nasional "Sekolah Sebagai Basis Pendidikan" Malang, 10 Juni 2000. Yang bersangkutan adalah Duta besar RI untu UNESCO 1985-1990. Anggota Executive Board UNESCO. Ketua Sub Komisi Pendidikan Tinggi Komisi IX DPR RI 1992-1997.

21. Lawrence E. Shapiro. How to Raise A Child with a High EQ: A Parents' Guide to Emotional Intelligence (terjemahan Alex Tri Kantjono dengan judul “ Mengajarkan Emotional Intelligence pada Anak), Jakarta: Gramedia Pustaka Utama, 1997, h. 46.

22. Lawrence E. Shapiro, How to Raise A Child with a High EQ: A Parents' Guide to Emotional Intelligence, h. 45.

23. Asrori. S. Karni, Laskar Pelangi: The Phenomenon, Jakarta: HikmahMizan, 2008, h. 161.

24. Barbara L. Martin \& Leslie J. Briggs, The Affective and Cognitive Domain: Integration for Instruction and Research, h. 147.

25. Robert E. Slavin. Educational Psychology: Theory and Practice (4 ${ }^{\text {th }}$ ed.). Needham Heights, Massachusset: Allyn and Bacon. 1994. p. 352.

26. David O. Sears, Jonathan 1. Freedman \& L. Anne Peplau, Social Psychology (5 $^{\text {th }}$ ed.), diterjemahkan oleh Michael Adrianto dengan judul Psikologi Sosial, Jakarta: Erlangga, 1988, h. 156.

27. Margaret E. Bell Gredler, Learning and Instruction: Theory into Practice. Terjemahan Munandir dengan judul "Belajar dan Membelajarkan" Jakarta: Rajawali Pers, 1991, h. 370.

28. Erik. H. Erikson, Identitas dan Siklus Hidup Manusia (Terjemahan Agus Cremers, Jakarta: Gramedia, 1989, h. 3. 
29. Norman A. Sprinthal \& Richard C. Sprinthal, Educational Psychology: A Developmental Approach (3rd ed.), New York: McGraw-Hill Publishing Company, 1990, h. 157.

30. Erik. H. Erikson, Identitas dan Siklus Hidup Manusia. Terjemahan Agus Cremers. Jakarta: Gramedia, 1989, p. 3.

31. Barbara Schneider Fuhrmann, Adolescence. Adolescents. (2nd ed.). Glenview, Illinois: Foresman and Company, 1990, h. 354.

32. James E. Gardner, The Turbulant Teens: Understanding, Helping, Surviving (Terjemahan Hadi Subrata dengan judul: Memahami Gejolak Masa Remaja) Jakarta: Mitra Utama, 1992, h. 30.

33. John Janeway Conger, Adolescence and Youth: Psychological Development in a Changing World (4th ed.), New York. NY: HarperCollins, 1991, h. 466.

34. Elizabeth E. Hurlock, Developmental Psychology: A Life Span Approach (5th ed.), terjemahan Istiwidayanti \& Soejarwo dengan judul Psikologi Perkembangan: Suatu Pendekatan Sepanjang Rentang Kehidupan, Jakarta: Erlangga, 1990, h. 225.

35. John Janeway Conger, Adolescence and Youth: Psychological Development in a Changing World (4th ed.), New York. NY: HarperCollins, 1991, h. 18.

36. Lawrence Kohlberg, Tahap-tahap Perkembangan Moral (Terjemahan John D. Santo \& Agus Cremers), Yogyakarta: Kanisius, 1995, h. 34.

37. John Janeway Conger, Adolescence and Youth: Psychological Development in a Changing World (4th ed.), New York. NY: HarperCollins, 1991, h. 592.

38. Calvin S. Hall \& Gardner Lindzey, Theories of Personality, terjemahan Yustinus dengan judul "Psikologi Kepribadian 1: Teori-teori Psiko-dinamik (Klinis). Yogyakarta: Kanisius, 1993, 64.

\section{DAFTAR PUSTAKA:}

Abdullah, M. Amin, Studi Agama: Normativitas atau Historisitas?, cet. I, Yogyakarta: Pustaka Pelajar, 1996.

Bulletin siang. RCTI, tanggal 2008.

Bulletin siang

Clabaugh, G. K., \& Razycki, Understanding School: The Fundamental of Education, New York: Harper \& Row, 1990.

Conger. J. J., Adolescence and Youth: Psychological Development in a Changing World (4th ed.), New York, NY: HarperCollins, 1991.

Donosepoetro, Marsetio, "Dinamika Perubahan Masyarakat dan Proses Pendidikan Nasional," Makalah, disampaikan pada Seminar Nasional "Sekolah Sebagai Basis Pendidikan," Malang, 10 Juni 2000. Yang bersangkutan adalah Duta besar RI untu UNESCO 1985-1990. Anggota Executive Board UNESCO. Ketua Sub Komisi Pendidikan Tinggi Komisi IX DPR RI 19921997.

Dryden, G \& Vos, J., The Learning Revolution: The Change the Way the World Learns, Torrance, CA, USA: The Learning Web, 1999.

Elliot, S. N., Kratochwill, T. R., Cook, J. L., \& Travers, J. E. Educational Psychology: Effective Teaching, Effective Learning ( ${ }^{\text {rd }}$ ed.). Boston: McGraw Hill. 
Erikson, E. H., Identitas dan Siklus Hidup Manusia (Terjemahan Agus Cremers), Jakarta: Gramedia, 1989.

Fuhrmann B. S., Adolescence. Adolescents, (2nd ed.). Glenview, Illinois: Foresman and Company, 1990.

Gardner J. E. The Turbulant Teens: Understanding, Helping, Surviving (Terjemahan Hadi Subrata dengan judul : Memahami Gejolak Masa Remaja) Jakarta: Mitra Utama, 1992.

George, R. L., \& Cristiany T. S. Counseling: Theory and Practice (3 ${ }^{\text {rd }}$ ed.). Needham Heights, MA: 1990.

Goleman, D. Emotional Intelligence. (Terjemahan Hermaya dengan judul "Emotional Intelligence; Kecerdasan Emosional) Jakarta: Gramedia Pustaka Utama, 1997.

Hall, C. S \& Gardner Lindzey, G. Theories of Personality. Terjemahan Yustinus dengan judul "Psikologi Kepribadian 1: Teori-Teori Psikodinamik (Klinis), Yogyakarta: Kanisius, 1993.

Gredler, M. E. Learning and Instruction: Theory into Practice. Trjemahan Munandir dengan judul "Belajar dan Membelajarkan" Jakarta: Rajawali Pers. 1991.

Hurlock, E. B. DevelopmentalPsychology: A Life Span Approach (5 $5^{\text {th }}$ ed.). Terjemahan Istiwidayanti \& Soejarwo dengan judul Psikologi Perkembangan: Suatu Pendekatan Sepanjang Rentang Kehidupan. Jakarta: Erlangga. 1990.

Karni, A. S. Laskar Pelangi: The Phenomenon.. Jakarta: HikmahMizan. 2008.

Kohlberg. L. Tahap-Tahap Perkembangan Moral (Terjemahan John D. Santo \& Agus Cremers). Yogyakarta. Kanisius. 1995.

Kohlberg (1963). The development of Children's Orientations toward a moral order; Sequence in the developmen of moral thought. (in Roger R. Hock (1999). Forty Studies that Changed Psychology. Upper Saddle River, New Jersey: Prentice Hall)..

Martin, B. L. \& Briggs, L. J. The Affective and Cognitive Domain: Integration for Instruction and Research. Englewood Cliffs, New Yersey: Educational Technology Publication, Inc. 1986.

Purwakania Hasan, A. B. Psikologi Perkembangan Islami: Menyingkap Rentang Kehidupan Manusia dari Prakelahiran hingga Pasca Kematian. Jakarta: RajaGrafindo Persada. 2006.

Schloss, P. J., \& Smith, M. A. Applied Behavior Analysis in the Classroom. Needham Heights, MA: Allyn and Bacon. 1994.

Sears, D. O., Freedman, J. L., \& Replau, L. A. Social Psychology (5 ${ }^{\text {th }}$ ed.). Terjemahan Michael Adrianto dengan judul Psikologi Sosial. Jakarta: Erlangga. 1988.

Shapiro, L. E. How to Raise A Child with a High EQ: A Parents' Guide to Emotional Intelligence (terjemahan Alex Tri Kantjono dengan judul " Mengajarkan Emotional Intelligence pada Anak). Jakarta: Gramedia Pustaka Utama, 1997.

Slavin, R. E. Educational Psychology (4th ed.). Needham Heights, Massachusset: Allyn and Bacon, 1994.

Sprinthal, N. A \& Sprinthal, R. C. Educational Psychology: A Developmental Approach (3 $3^{\text {rd }}$ ed.), New York: McGraw-Hill Publishing Company, 1990. 